\title{
WADAH KREATIVITAS-BERBASIS-PLASTIK
}

\author{
Putri Odelia ${ }^{1)}$, Alvin Hadiwono ${ }^{2)}$ \\ 1)Program Studi S1 Arsitektur, Fakultas Teknik, Universitas Tarumanagara, putrio.ta@stu.untar.ac.id \\ ${ }^{2)}$ Program Studi S1 Arsitektur, Fakultas Teknik, Universitas Tarumanagara, alvinhadiwono@ymail.com
}

\begin{abstract}
Abstrak
Jakarta menduduki peringkat tertinggi kedua sebagai kota yang menghasilkan sampah paling banyak. Kota Jakarta menghasilkan sekitar tujuh ribu ton sampah setiap harinya. Namun, hanya sebanyak enam ribu ton sampah yang dapat diangkut ke Tempat Pembuangan Akhir Bantar Gebang per hari. Sebagian sisa sampah yang tidak terangkut ini kemudian menumpuk pada lahan kosong dan jalur air, seperti sungai dan kali. Ditambah lagi kebiasaan masyarakat yang masih kurang peduli terhadap lingkungan dengan membuang sampah sembarangan, termasuk ke sungai atau kali, membuat pencemaran sampah plastik ini semakin meningkat. Sampah yang tidak terangkut ini kemudian mengalir sampai ke laut. Di laut, sampah plastik yang diabaikan, tidak akan teurai dalam waktu singkat. Penumpukan sampah ini kemudian mengganggu kehidupan biota laut. Dalam proses perbaikan dan pemeliharaan lingkungan, peran masyarakat di sekitarnya merupakan faktor penting. Masyarakat harus ambil bagian dalam menjalani kehidupan sehari-hari, seperti: mengurangi penggunaan plastik sekali pakai, memilah sampah sebelum dibuang, mendaur ulang sampah menjadi benda baru yang bernilai, dan sebagainya. Oleh karena itu desain bangunan ini bertujuan sebagai sarana masyarakat untuk belajar dan ikut serta dalam penanganan isu yang terjadi di kawasan ini. Bangunan arsitektural, sebagai tempat yang mewadahi kegiatan masyarakat ini menggunakan prinsip-prinsip plastisitas sebagai dasar membentuk massa dan ruang.
\end{abstract}

\section{Kata kunci: laut; plastik; plastisitas; sampah}

\begin{abstract}
Jakarta ranks as the highest as the city that produces the most waste after China. Jakarta produces around seven thousand tons of waste every day. However, only six thousand tons of garbage can be transported to the Bantar Gebang Final Disposal Site per day. Some of the waste that is not transported then piles up on empty land and waterways, such as rivers and streams. Plus the habits of people who are still less concerned about the environment by littering, including in rivers or streams, make this plastic waste pollution increasing. Waste that is not transported then flows to the sea. At the sea, neglected plastic rubbish will not be decomposed in a short time. This accumulation of garbage then disrupts the life of marine life. In the process of environmental improvement and maintenance, the role of the surrounding community is an important factor. The community must take part in living their daily lives, such as: reducing the use of disposable plastics, sorting out trash before disposal, recycling waste into new valuable objects, and so on. Therefore this building design aims as a means for the community to learn and participate in handling issues that occur in this region. Architectural building, as a place that accommodates community activities, uses the principles of plasticity as the basis for forming mass and space.
\end{abstract}

\section{Keywords: plastic; plasticity; sea; trash}

\section{PENDAHULUAN}

Indonesia memiliki masalah serius dalam hal limbah plastik. Saat ini, Indonesia menduduki peringkat kedua teratas sebagai negara penghasil sampah plastik di laut setelah Cina (CNBC Indonesia). Menurut penelitian, pada tahun 2010 Indonesia menyumbang 3,22 juta ton 
sampah plastik yang dibuang ke laut (Jambeck, 2015). Krisis sampah plastik ini tidak hanya mencemari lautan, tetapi juga ikut mempengaruhi sungai di Indonesia. Pada tahun 2018, Indonesia menerina impor sampah plastik hingga 320 ribu ton dalam satu tahun (CNBC Indonesia). Jumlah ini melonjak sebasar $150 \%$ dari tahun sebelumnya. Hal ini disebabkan oleh pemerintah Cina yang membatasi impor sampah plastik, sehingga negara-negara ASEAN menjadi pilihan utama dalam mengimpor sampah. Jakarta sendiri menduduki peringkat tertinggi kedua sebagai kota yang menghasilkan sampah paling banyak. Kota Jakarta menghasilkan sekitar tujuh ribu ton sampah setiap harinya. Namun, hanya sebanyak enam ribu ton sampah yang dapat diangkut ke Tempat Pembuangan Akhir Bantar Gebang per hari. Sebagian sisa sampah yang tidak terangkut ini kemudian menumpuk di beberapa daerah. Penumpukan sampah yang paling sering kita temui berada di jalur air, seperti sungai dan kali. Ditambah lagi kebiasaan masyarakat yang masih kurang peduli terhadap lingkungan dengan membuang sampah sembarangan, termasuk ke sungai atau kali, membuat pencemaran sampah plastik ini semakin meningkat. Sampah yang tidak terangkut ini kemudian mengalir sampai ke laut.

\section{Jumlah Polusi Laut atas Sampah Plastik (juta ton/tahun)}

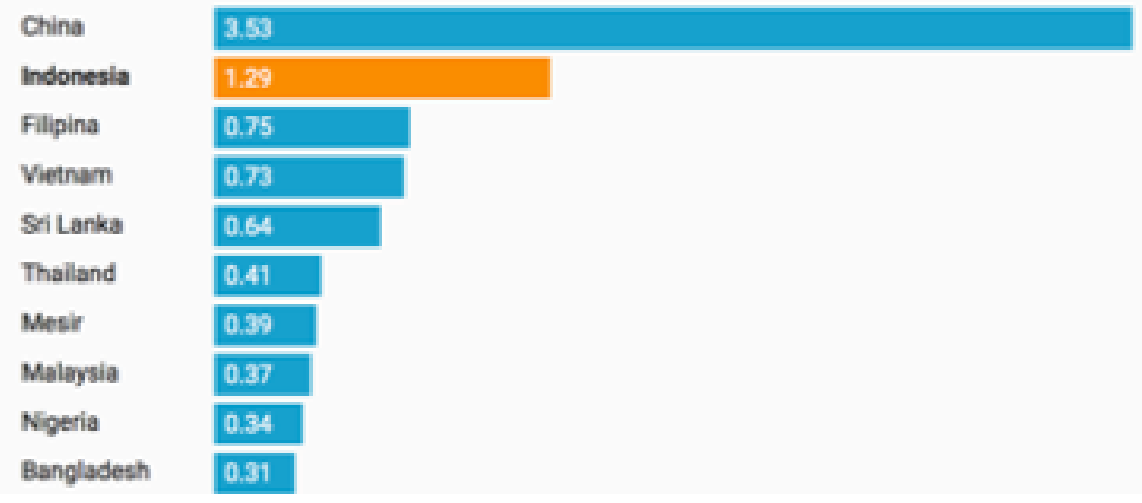

Gambar 1. Jumlah Polusi Laut atas Sampah Plastik per Tahun

Sumber: CNBC Indonesia

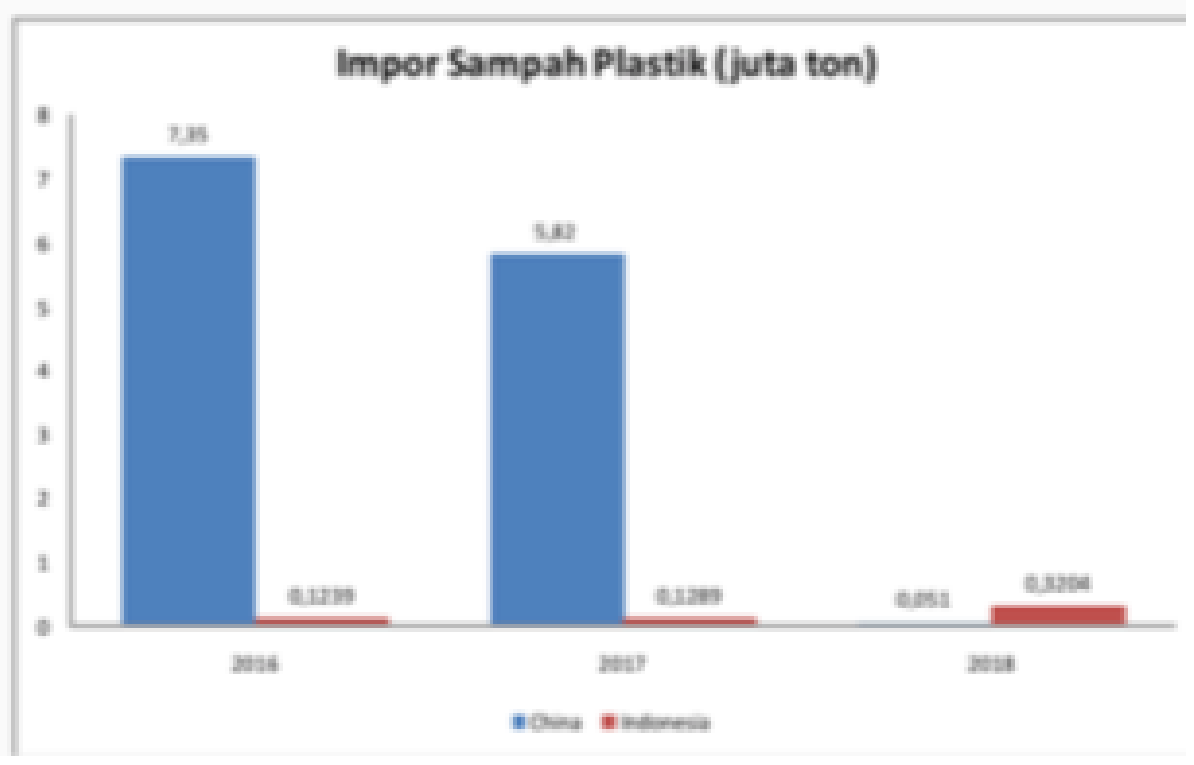

Gambar 2. Jumlah Impor Sampah Plastik per Tahun

Sumber: CNBC Indonesia 


\section{KAJIAN LITERATUR}

Ruang (space) atau tempat (place) ada dua kata yang sering kita temukan dalam istilah arsitektur. Namun pengertiannya sering terkesan 'campur aduk' sehingga membiaskan makna dari masing-masing kata tersebut. Tidak hanya pada bidang ilmu arsitektur, kedua kata ini sering ditemukan dalam bidang ilmu lain seperti sains. Dalam bidang arsitektur, ruang dan tempat berhubungan dengan perasaan (feel) dan pengalaman (experience).

Kata ruang (space) berasal dari Bahasa Latin, yaitu spatium yang berarti ruangan atau luas (extent). Dalam Bahasa Yunani, ruang diartikan sebagai tempat (topos) atau lokasi (choros) yaitu ruang yang memiliki ekspresi kualitas tiga dimensi. Menurut Aristoteles, ruang adalah sesuatu yang terukur dan terlihat, dibatasi oleh kejelasan fisik, enclosure yang terlihat sehingga dapat dipahami keberadaannya dengan jelas. Namun Yi Fu Tuan (1997) berpendapat bahwa ruang lebih abstrak daripada tempat.

Pendapat Yi Fu Tuan didasarkan pada kondisi dimana setelah seseorang mengalami sebuah ruang, maka individu ini akan menangkap nilai-nilai yang hadir di ruang tersebut. Dari nilai-nilai inilah kemudian individu menentukan sebuah ruang merupakan tempat (place) atau bukan. Oleh karena itu kehadiran tempat harus didahului dengan kehadiran sebuah ruang.

Arsitektur berkembang tidak dengan sendirinya, melainkan ada peran masyarakat sebagai pengguna yang turut membentuk perencanaan dan perancangan dalam arsitektur. Umumnya perubahan yang turut serta secara langsung dalam membentuk sebuah arsitektur adalah pola perilaku atau kebiasaan yang terjadi dalam masyarakat tersebut. Hal lainnya yang juga berkaitan dengan dengan perubahan ini adalah terjadinya pergeseran norma dan nilai dalam masyarakat. Hal ini menuntut arsitektur untuk terus berkembang seiring dengan perubahan yang terjadi dalam masyarakat.

Contoh yang sangat umum terjadi saat ini adalah bagaimana sebuah cafe sedikit demi sedikit bergeser fungsi, yang awalnya merupakan penyedia ruang untuk duduk berbincang menjadi tempat yang digunakan untuk bekerja. Di era digital seperti saat ini, kebiasaan seperti ini bukan hal yang jarang dilakukan. Terutama bagi para pekerja lepas, yang membutuhkan tempat bekerja dengan suasana nyaman dan tidak formal. Dengan hadirnya kebutuhan seperti ini, secara tidak langsung juga menggeser tipologi dari sebuah cafe. Munculnya pergeseran ini yang membentuk objek arsitektur yang disebut the third place.

Dalam membangun sebuah komunitas, the third place (tempat ketiga) adalah sebuah lingkungan sosial yang berbeda dari lingkungan rumah (the first place) dan kantor (the second place). The third place merupakan ruang publik yang netral. Contohnya seperti: gereja, cafe, perpustakaan umum, toilet, taman, dll. Menurut Ray Oldenburg (1989), the third place merupakan unsur penting bagi masyarakat sipil, demokrasi, keterlibatan sipil, dan membangun perasaan terhadap sebuah tempat. The third place merupakan sebuah 'jangkar' dalam membentuk sebuah komunitas, dan harus mampu memfasilitasi kegiatan di dalamnya.

Ray Oldenburg menjelaskan ada 8 karakteristik third place, yaitu:

a. Neutral ground - Penggunanya tidak terpisah secara finansial, politikal, legal, dll. Seluruh penggunanya memiliki hak yang sama.

b. A leveling place - Tidak mementingkan status sosial bagi siapapun penggunanya.

c. Conversation is the main activity - percakapan yang menyenangkan menjadi fokus utama dalam membangun aktivitas.

d. Accessibility and accommodation - Third place harus dapat diakses oleh semua individu, dan harus mampu menyediakan tempat dengan multi-program.

e. The regulars - memiliki 'pengunjung tetap' namun tetap mampu menarik pengunjung baru.

f. A low profile - third place pada dasarnya merupakan tempat yang sederhana (human scale), dan dapat menerima semua individu.

g. The mood is playful - tidak menimbulkan permasalahan antar-individu di dalamnya, melainkan menciptakan suasananya yang ceria.

h. A home away from home - mampu menimbulkan rasa nyaman seperti di rumah, namun dilain sisi juga memberikan efek yang me-retreat. 
Melalui karakteristik ini, menunjukan bahwa mendesain third place dipengaruhi oleh kebiasaan masyarakat sebagai penentu aktivitas di dalamnya. Sekaligus memberikan efek kepada pengguna dan masyarakat di sekitarnya. Dalam sejarah peradaban manusia, third place sudah muncul sejak pertama kali manusia mulai hidup menetap. Pada masa ini, third place muncul dalam berbagai jenis ruang, baik di dalam bangunan maupun di luar. Di Indonesia sendiri, kita dapat melihat keduanya. Masyarakat menggunakan ruang publik sebagai tempat pelaksanaan acara adat. Pada saat itulah, third place terbentuk dalam peradaban masyarakat kuno.

Di beberapa tempat di Indonesia, masih terdapat bentuk-bentuk third place yang tercipta dari peradaban lama ini. Contohnya seperti Pura Uluwatu yang menyajikan tarian kecak. Namun pada daerah urban atau kota, tempat-tempat seperti ini semakin memudar keberadaannya karena kondisi kehidupan yang tidak sama seperti di daerah pedesaan. Kebiasaan-kebiasaan masyarakatnya sudah berubah, terutama oleh karena tren yang sangat cepat berganti dan menjadi serba instant.

Masyarakat perkotaan lebih senang mencari hiburan atau sekedar bertemu dengan kerabat di pusat perbelanjaan atau cafe dan restoran. Ditambah lagi dengan teknologi yang sangat menjamur, memberikan siapa saja kesempatan untuk berkomunikasi secara virtual, mendorong masyarakat untuk semakin tidak memerlukan ruang publik. Lama-kelamaan, ruang-ruang publik akan menghilang digantikan oleh ruang virtual. Open Architecture didefinisikan sebagai third place dengan melihat hal-hal penting yang berkaitan dengan konteks kebutuhan masyarakat kota dan modernitas yang berorientasi pada teknologi informasi dan individu. Namun kebutuhan masyarakat kota menimbulkan konflik seperti: public - private-blur, closeness - openness-voidness, transparent - translucent-opaque, exclusive - inclusive-speciality, natural - artificial-superficial, interior - exterior - mobius, dan bounderies - edges-teritories.

Dalam merancang arsitektur, masyarakat kota lebih cenderung memiliki sensitivitas terhadap personal space-nya. Masyarakat modern lebih individual dan kondisi ini menyebabkan publik scape kehilangan daya tariknya. Masyarakat lebih memilih memiliki ruang personal masing-masing, sehingga terdapat pembagian ruang publik dan privat yang terlihat sangat jelas. Dinding menjadi batas ruang yang jelas dan solid.

Merancang the third place dapat dikatakan sebagai meracang masyarakat perkotaan, karena diharuskan memenuhi kebutuh ruang publik namun dengan sifat masyarakat yang individualis. Maka dari itu dibutuhkan karakteristik-karakteristik sebagai tolok ukur perancangan. Menurut Agustinus Sutanto (2019), karakteristik dalam merancang the third place adalah:

a. Opens

- Promoting inclusiveness \& equality (poor \& rich)

- A world of strangers

- Permeability (social impact \& rembesan movement)

- Place for information changes

b. Flexibility

- Freedom of how to occupy the place

- Possibilities for hybrid programming

c. Contextuality

- Local identity

- Answering the people's need

\section{METODE}

Data yang dikumpulkan berupa data persebaran sampah plastik di Indonesia dan Jakarta, peta jalur sungai di Jakarta, data kependudukan kawasan Muara Angke, sarana dan prasarana kawasan, peta zonasi, peta jalur kendaraan umum, peta ketinggian bangunan, dan kegiatan penduduk Muara Angke. Metode yang digunakan dalam pengumpulan data tersebut adalah 
metode survey lapangan, wawancara, dan studi pustaka. Tahap penelitian berlangsung selama kurang lebih 2 bulan. Selama tahap penelitian ini, didapatkan beberapa data mengenai kawasan, kependudukan, dan isu-isu yang terjadi di kawasan ini. Isu ini berkaitan dengan penduduk kawasan Muara Angke.

Data yang telah dikumpulkan dari tahap penelitian kemudian dianalisis bersamaan dengan dengan data tapak yang akan didesain. Analisis pada tahap ini menggunakan metode analisissintesis untuk menghasilkan analisis tapak. Data analisis tapak kemudian digunakan sebagai dasar mendesain.

\section{DISKUSI DAN HASIL}

Pada tahun 2019, Jakarta terecatat menghasilkan sampah sebanyak 7.700 ton per hari, dengan 250 ton yang terangkut berasal dari badan air. Sebagai ibu kota yang memiliki tingkat kepadatan penduduk yang tinggi, sebagian besar sampah merupakan

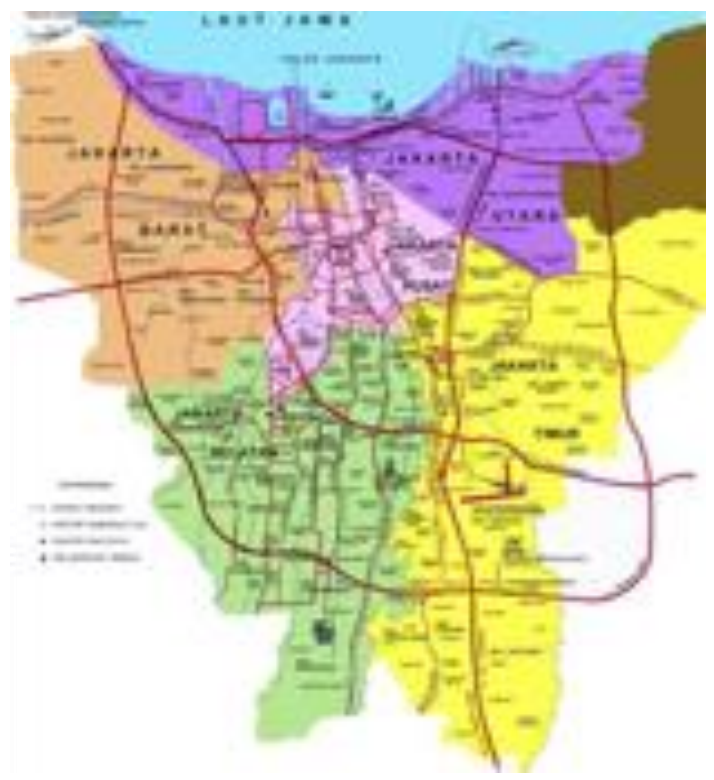

Gambar 3. Peta Kota Jakarta

Sumber: (https://www.google.co.id/peta-sungai-jakarta)

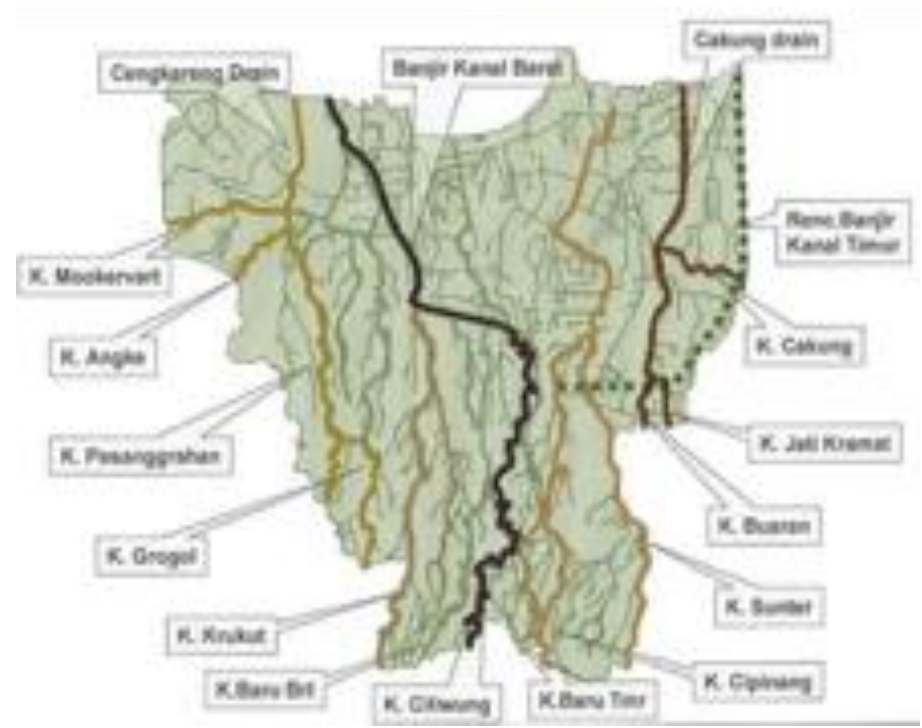

Gambar 4. Peta Aliran Sungai Di Jakarta

Sumber: (https://www.google.co.id/peta-sungai-jakarta) 
Teluk Jakarta juga menjadi tempat bermuara beberapa sungai. Hal ini menyebabkan menumpuknya sampah plastik yang dibawa dari masing- masing aliran sungai ke Teluk Jakarta. Jakarta Utara juga menjadi salah satu kawasan industri, dimana limbah industri banyak dihasilkan.

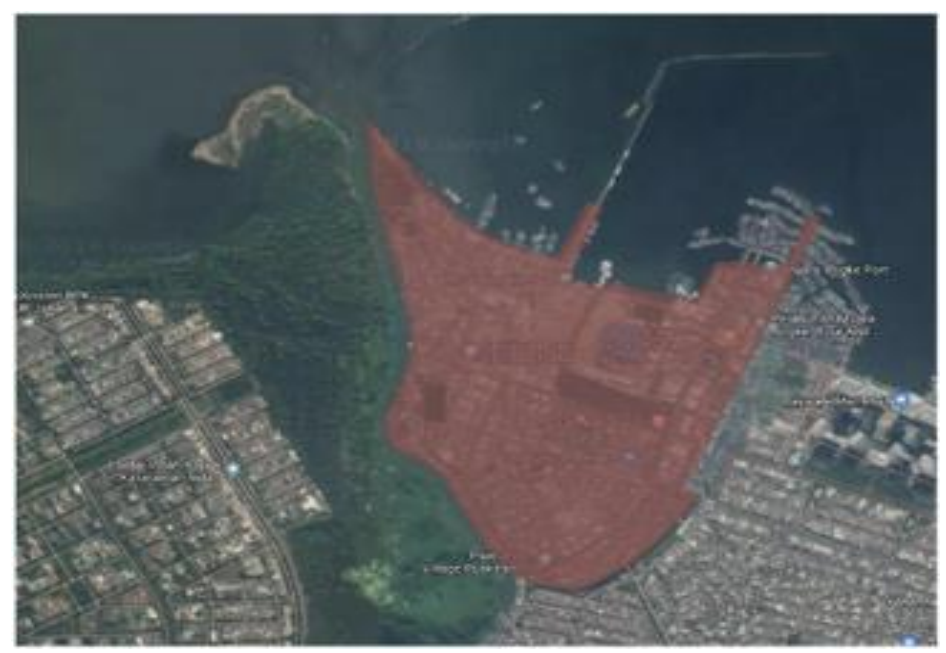

Gambar 5. Peta Kawasan Muara Angke

Sumber: Penulis, 2019

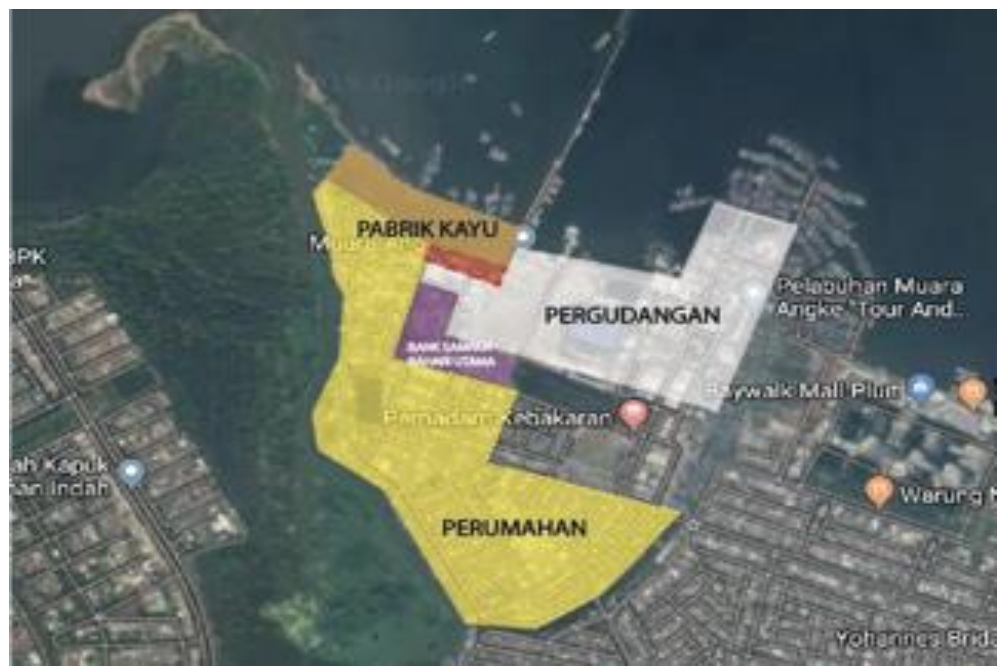

Gambar 6. Peta Zonasi Eksisting Kawasan Muara Angke

Sumber: Penulis, 2019

Muara Angke dikelilingi oleh aliran sungai sekaligus menjadi pertemuan dengan laut. Muara Angke dilewati oleh aliran Sungai Banjir Kanal Barat dan bermuara di teluk Jakarta. Untuk menahan abrasi dari Teluk Jakarta, pesisir Muara Angke ditanami tanaman bakau. Tanaman ini kemudian berfungsi juga sebagai penyaring sampah yang mengalir ke laut. Sayangnya, sampah ini kemudian tertimbun dan tidak terurus.

Pada tahun 2018, pemerintah DKI Jakarta memulai penertiban di kawasan Muara Angke dan melalukan pengangkutan sampah dari hutan mangroove di muara angke. Sebanyak lima puluh ton sampah telah diangkat pada pertama kalinya, kemudian pengangkutan terus dilakukan guna pemeliharaan kawasan hutan mangroove. Dengan volume sampah yang terus meningkat, pengangkutan sampah plastik tanpa pengolahannya akan menimbulkan masalah baru, yakni tidak tersedianya tempat penampungan sampah tersebut. Oleh karena itu diperlukan keikutsertaan dari masyarakat untuk mengurangi dan mengolah kembali sampah yang dihasilkan. 


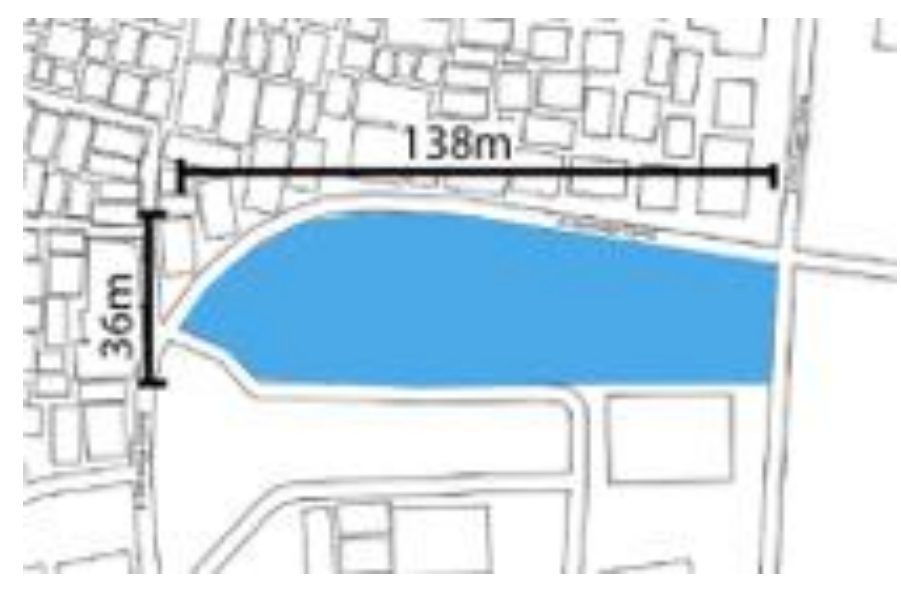

Data Tapak

Lokasi : Kelurahan Pluit, Kecamatan Penjaringan

Zonasi : Perkantoran dan jasa

KDB : $30 \%$

$\mathrm{KLB}: 1,2$

$\mathrm{KB}: 4$

$\mathrm{KDH}: 45 \%$

Gambar 7. Peta Kawasan Muara Angke

Sumber: Penulis, 2019
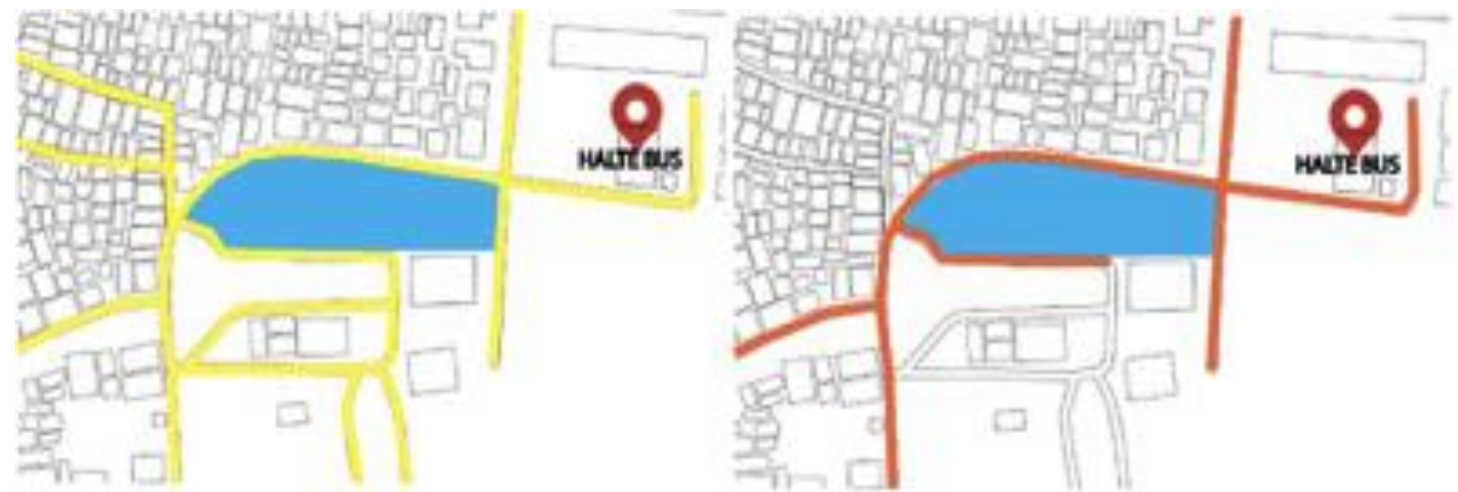

JALUR PEDESTRIAN

JALUR KENDARAAN UMUM

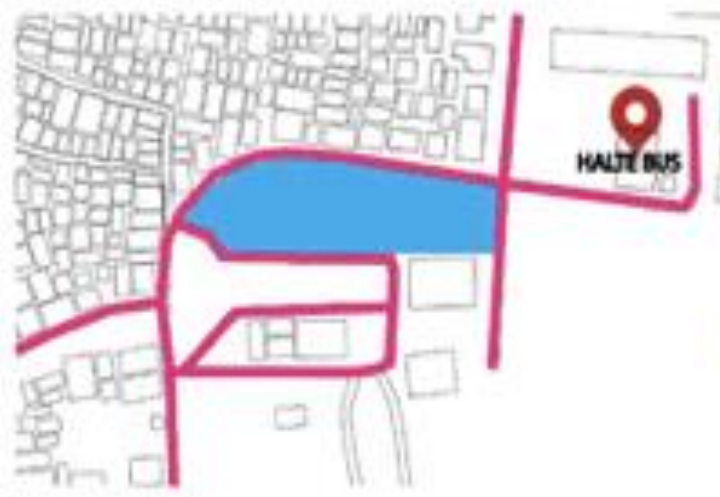

JALUR MOBIL

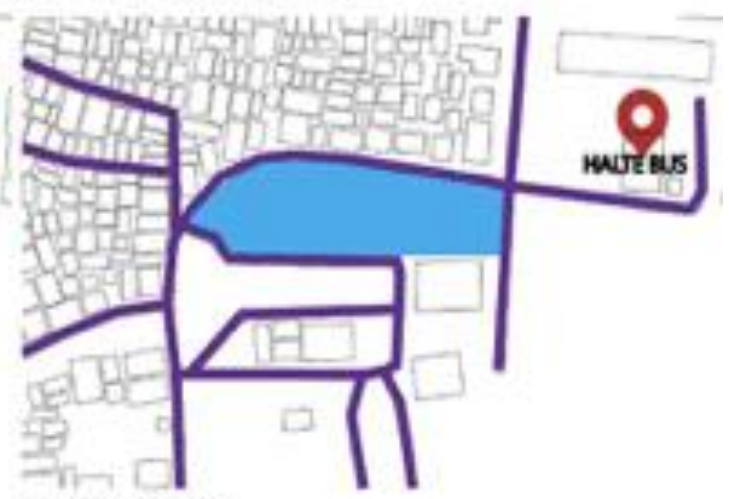

JALUR MOTOR

Gambar 8. Peta Jalur Kendaraan dan Pejalan Kaki di Sekitar Tapak

Sumber: Penulis, 2019

Jika dilihat dari aktivitas penduduk di sekitar tapak, maka didapatkan bahwa calon pengguna bangunan ini didominasi oleh anak-anak usia sekolah. Hal ini disebabkan oleh sangat minimnya sarana dan prasarana yang memadai untuk menampung kegiatan bermain dan belajar non-formal bagi anak-anak di kawasan Muara Angke ini. Sehingga kebanyakan dari anak-anak ini bermain di lingkungan yang kurang bersih dan tidak ramah anak. 


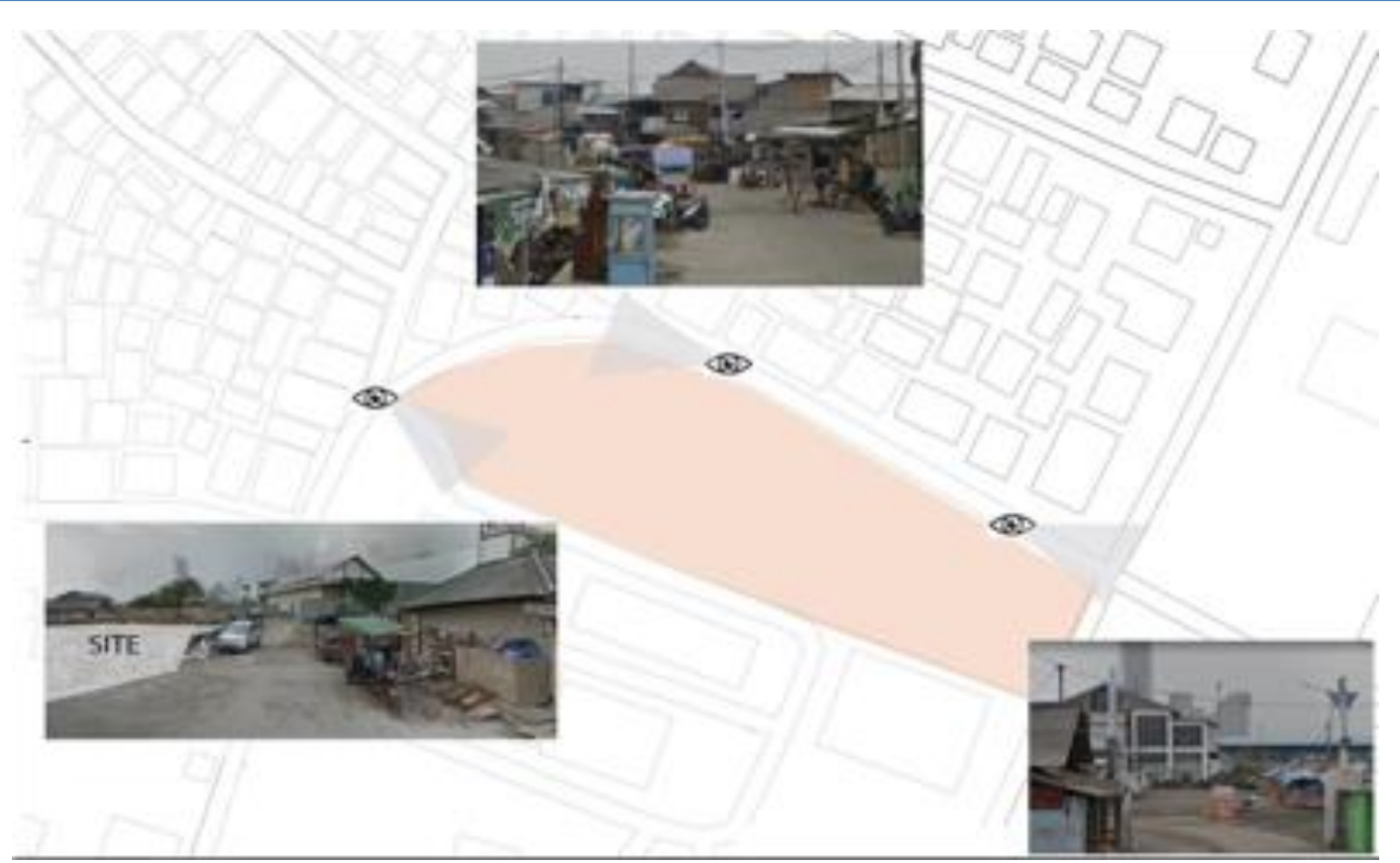

Gambar 9. Peta Kegiatan Penduduk Sekitar Tapak

Sumber: Penulis, 2019

Sebagian besar aktivitas yang dominan di sekitar tapak adalah kegiatan hunian, hunian sekaligus pertokoan, dan pergudangan. Posisi tapak yang berada diantara lokasi rumah dan tempat kerja menjadi nilai positif untuk menarik perhatian penggunanya sebagai tempah singgah sementara. Sedangkan diakhir pekan, program-program yang muncul dapat menjadi program rekreasi singkat bagi masyarakat sekitar.

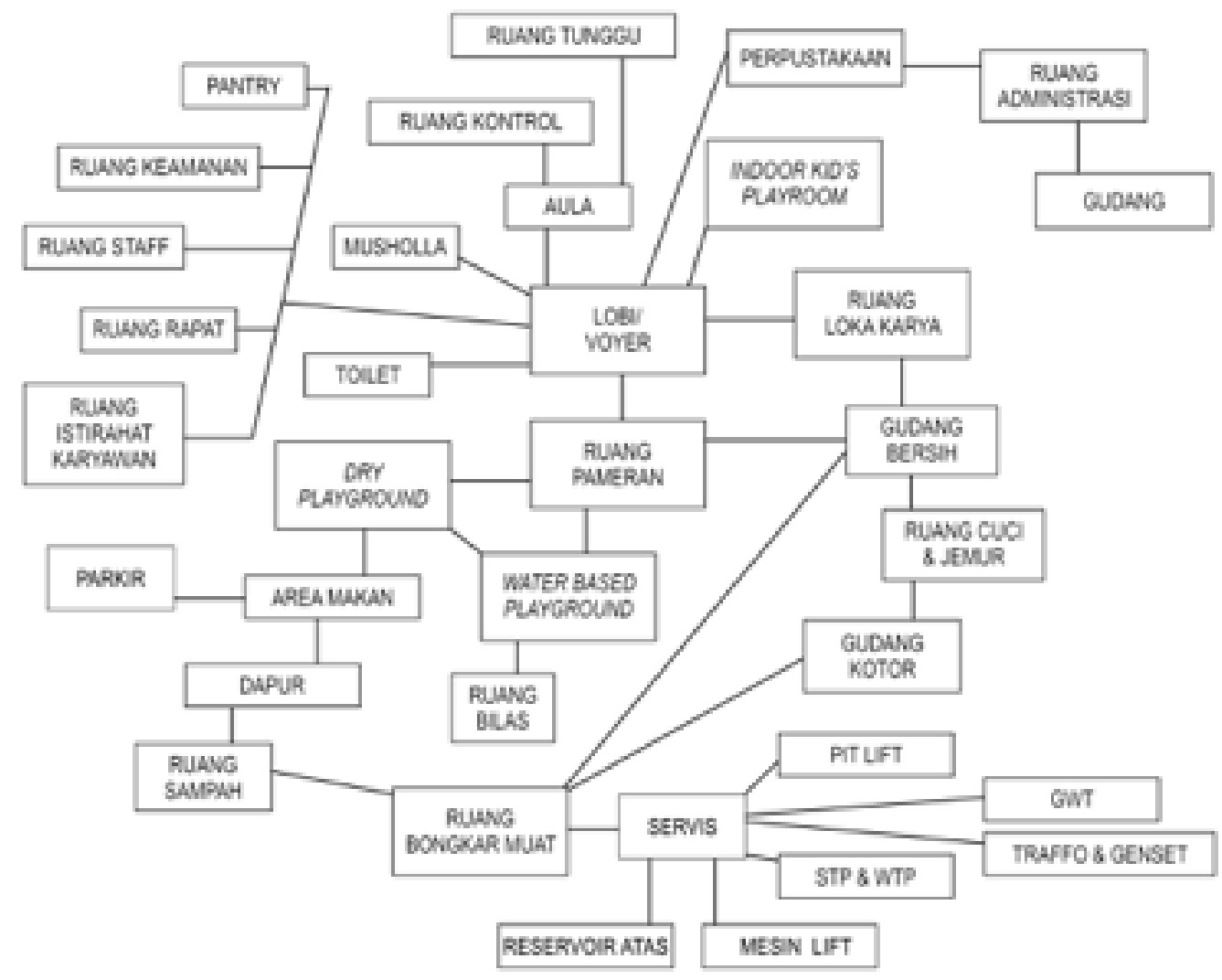

Gambar 10. Skema Hubungan Ruang

Sumber: Penulis, 2019 
Program ruang Wadah Kreativitas-Berbasis-Plastik ini terdiri dari:

a. Area bermain (basah)

- Area ini didesain ramah anak, bertujuan agar dapat menjadi tempat tujuan rekreasi sementara bagi anak-anak di lingkungan Muara Angke.

- Area ini dikhususkan untuk permainan yang menggunakan air sebagai media bermainnya. Hal ini bertujuan untuk menyadarkan masyarakat akan pentingnya air bersih. Sekaligus bertujuan untuk membentuk kebiasaan masyarakat untuk menggunakan air bersih.

b. Area bermain (kering)

- Area ini didesain ramah anak, bertujuan agar dapat menjadi tempat tujuan rekreasi sementara bagi anak-anak di lingkungan Muara Angke.

- Area ini dikhususkan untuk permainan yang tidak menggunakan air sebagai media bermainnya.

c. Area bermain (indoor)

- Area ini didesain ramah anak, bertujuan agar dapat menjadi tempat tujuan rekreasi sementara bagi anak-anak di lingkungan Muara Angke.

- Area ini dikhususkan untuk sarana bermain sekaligus belajar bagi anak. Hal ini bertujuan untuk mengajarkan dan membentuk kebiasaan untuk tidak membuang sampah sembarangan.

- Ruang bermain ini merupakan ruang tematik, dengan tema plasticity.

d. Area workshop dan pameran

- Berdasarkan jenis kegiatan, ruang workshop dibagi menjadi dua bagian, ruang workshop singkat dan ruang workshop berkelanjutkan.

- Ruang workshop singkat mengakomodir kegiatan mengolah sampah plastik yang sudah dibersihkan menjadi benda baru yang berguna; seperti gantungan kunci, pajangan, tempat pensil, dll.

- Sedangkan workshop berkelanjutan mengakomodir kegiatan pembelajaran membuat instalasi informatif tentang sampah plastik di laut. Hasil dari workshop ini kemudian akan dipajang di Ruang Pameran. Ruang workshop berkelanjutan dapat mengakomodir bahan baku seperti kayu dengan panjang maksimal 4 meter.

- Area workshop dan pameran dihubungkan melalui ruang servis dan memiliki akses langsung ke gudang bahan baku kotor, ruang cuci-jemur, gudang bahan baku bersih.

e. Perpustakaan

- Perpustakaan dapat mengakomodir kegiatan pinjam-meminjam, kegiatan membaca, belajar, dan diskusi kelompok.

- Perputakaan memiliki ruang administrasi dan gudang yang terpisah dengan fungsi lain dalam bangunan. Namun tetap berada pada satu jalur servis yang sama.

f. Aula

- Ruang ini bertujuan sebagai tempat berkumpul penduduk saat mengadakan acara lingkungan.

g. Food Court

- Sebagai tempat jual-beli makanan, untuk para pekerja dan siapa saja orang yang melintasi tapak.

- Sekaligus menyediakan area tempat makan.

h. Area privat dan servis

- Yang termasuk dalam area privat adalah kantor pengelola dan ruang karyawan. Sedangkan yang termasuk dalam area servis adalah dapur, gudang, tempat cuci-jemur sampah plastik, parkir, dan sirkulasinya.

Bangunan mengambil konsep Third place sebagai dasar pembentukan fungsi dan ruang. Kemudian untuk menjawab isu lingkungan yang muncul, digunakan istilah "plasticity" sebagai tema dari bangunan ini. Tema ini berperan dalam pembentukan massa bangunan dan beberapa ruang tematik di dalamnya. 


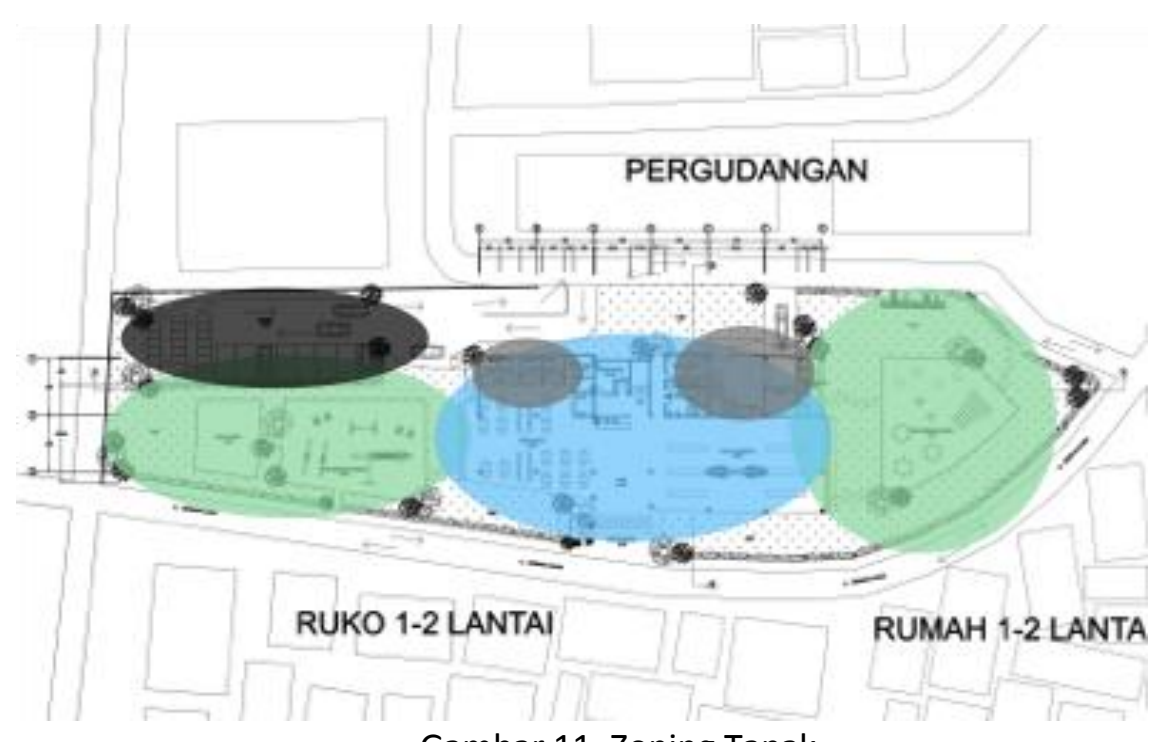

Gambar 11. Zoning Tapak

Sumber: Penulis, 2019

Proses desain dimulai dari membagi zona pada tapak. Warna hijau merupakan zona ruang hijau dan ruang terbuka, warna biru sebagai zona ruang publik, warna abu-abu sebagai zona servis dan privat, warna hitam sebagai zona parkir. Tapak menghadap ke arah Timur Laut. Orientasi bangunan ditentukan dari sisi bangunan yang memiliki intensitas pengguna jalan tertinggi. Keempat sisi bangunan akan terus mendapat cahaya matahari alami sepanjang hari. Tapak terletak kurang lebih $\mathbf{1 0 0}$ meter dari pinggir laut dan bersebelahan dengan Pelabuhan Kali Adem. Di dalam tapak, tidak dibuat basement, oleh karena itu parkir berada di ruang terbuka dan hanya beberapa ruang servis yang berada di bawah lantai dasar.

Target pengguna bangunan ini adalah penduduk di kawasan Muara Angke dan sekitarnya. Oleh karena itu, jalir pedestrian dan pintu masuk pejalan kaki serta pengguna sepeda menjadi akses utama keluar masuk tapak dan bangunan. Sedangkan untuk kendaraan bermotor disediakan beberapa tempat parkir motor, mobil, dan mobil servis.

Pada pengolahan zoning, ruang terbuka diletakan pada bagian kiri dan kana tapak. Hal ini bertujuan untuk menarik pengunjung dari kedua sudut jalan. Menurut hasil analisa lingkungan, jalan dengan intensitas pengguna paling tinggi merupakan jalan yang berada di sisi depan tapak. Sehingga sisi depan tapak dideasin untuk ramah pejalan kaki, tanpa adanya pertemuan dengan jalur kendaraan keluar masuk tapak. Pada kondisi eksisting saat ini, jalur pedestrian jumlahnya sangat minim. Pejalan kaki berada pada satu level ketinggian jalan dengan kendaraan bermotor. Untuk mengakomodir kebutuhan pejalan kaki menuju dan dari tapak, maka dibuatkan jalur pedestrian di sekeliling tapak. Sekaligus untuk mengakomodir kebutuhan akses ke dan dari halte busway di sebelah tapak.

Jalur kendaraan dan servis di letakan di bagian belakang tapak dengan tujuan untuk mengurangi pertemuan dengan jalur pejalan kaki. Sisi belakang dipilih karena intensitas penggunaan kendaraan beroda empat atau lebih, paling tinggi berada di jalan pada sisi belakang tapak. Tapak tidak dikelilingi pagar atau dinding, sebagai tanda bahwa setiap orang dapat masuk dan menggunakan fungsi-fungsi yang ada di dalamnya. Selain itu, hal ini juga untuk mempermudah pengawasan keamanan bangunan dari semua sisi baik dari dalam, maupun dari luar bangunan. Sehingga dapat meminimalisir penggunaan petugas keamanan.

Tampak bangunan dibentuk berdasarkan tema, yaitu "plasticity". Bagian luar fasad bangunan diberi kisi-kisi dengan bentuk bergelombang sebagai simbol dari sifat plastik. Kisi-kisi ini menggunakan bahan kayu. Kayu yang berdiri sendiri tidak memperlihatkan sifat plastisitas, namun rangkaian dari banyak kayu dapat menghasilkan sebuah bentuk yang plastis. Tiga sisi bangunan (kiri, depan, kanan) menggunakan kisi-kisi di bagian luarnya untuk menambah kesal plastisitas. 


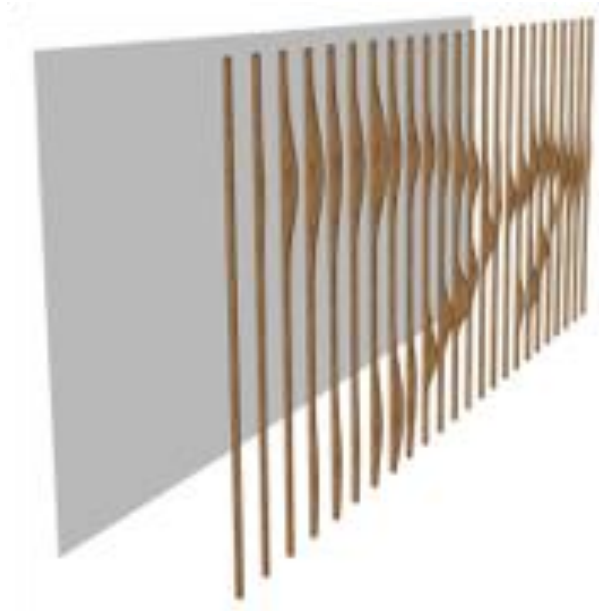

Gambar 12. Kisi-kisi Tampak Bangunan Sumber: Penulis, 2019

Setiap ruang dalam bangunan memiliki jendela untuk sirkulasi udara. Sekaligus mengurangi penggunaan pendingin ruangan, dan memaksimalkan penggunaan udara alami. Jendela juga berfungsi untuk masuknya cahaya matahari dan mengurangi penggunaan lampu di dalam ruangan. Selain itu, dengan banyak jendela, membuat pengguna dari luar bangunan dapat melihat sekilas kegiatan di dalam bangunan dan memberikan kesempatan untuk datangnya pengunjung baru setiap hari.

Bangunan menggunakan struktur balok dan kolom, tanpa core bangunan. Material yang digunakan untuk struktur balok, kolom, plat lantai, dan tangga adalah beton bertulang. Sedangkan untuk dinding basement menggunakan retaining wall. Akses vertikal lift menggunakan material baja. Struktur atap menggunakan dak beton dan baja bidang pada bentang lebar. Penutup atap bentang lebar menggunakan UPVC.

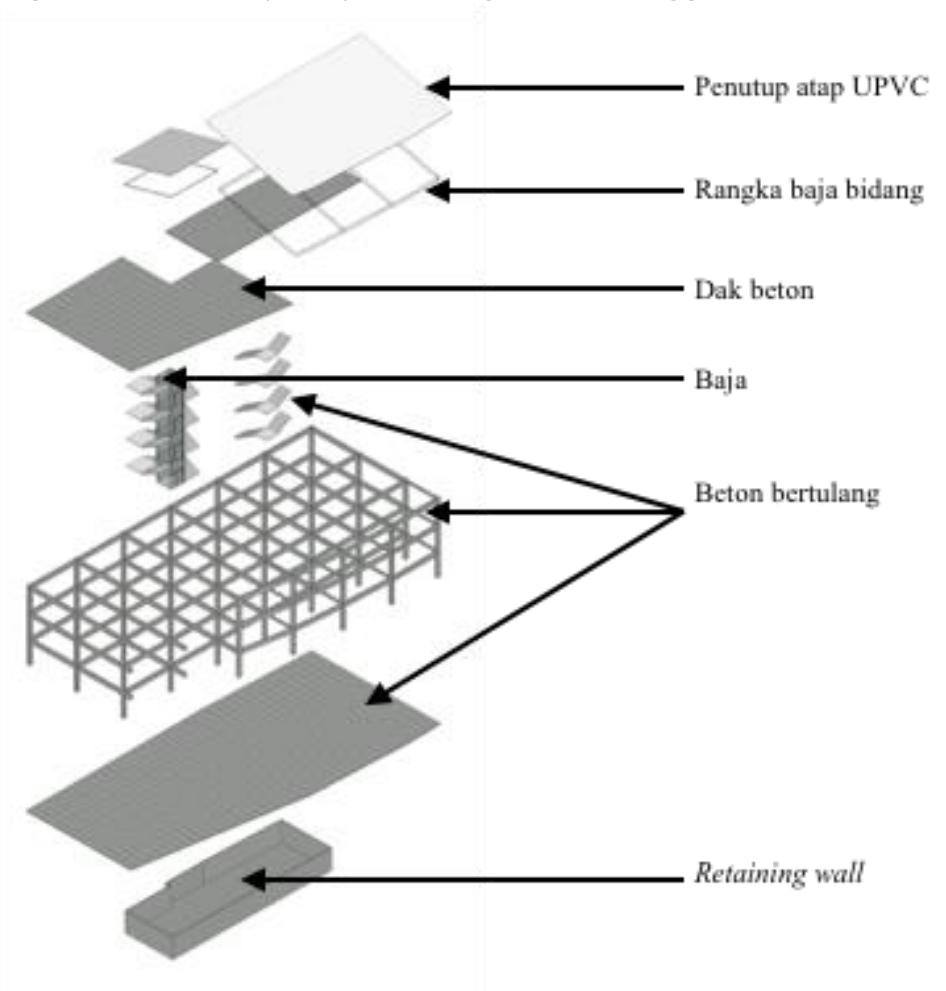

Gambar 13. Struktur Bangunan

Sumber: Penulis, 2019 


\section{KESIMPULAN DAN SARAN}

Sampah plastik merupakan krisis yang sedang melanda dunia, termasuk Indonesia. Teluk Jakarta turut merasakan dampak dari tertimbunnya sampah plastik dan kurangnya penganangan yang baik. Berdasarkan riset yang dilakukan berbagai lembaga, dapat dilihat masalah yang bersangkutan dengan isu ini antara lain:

1. Kurangnya kesadaran masyarakat untuk ikut serta dalam proses pengurangan dan pengolahan sampah, khususnya sampah plastik.

2. Terbatasnya lahan Tempat Pembuangan Akhir (TPA) yang mengakibatkan sisa sampah yang tidak terangkut dibuang ke laut.

3. Masih maraknya penggunaan plastik sekali pakai, serta kebiasaan masyarakat membuang sampah sembarangan.

4. Kurangnya pengetahuan tentang memilah sampah dan mendaur ulang sampah plastik.

5. Kurangnya kegiatan penyuluhan yang mendekatkan diri kepada masyarakat di berbagai daerah, khususnya daerah pesisir Jakarta.

Oleh karena itu, proyek third place dengan tema plasticity yang ramah bagi lingkungan dan menarik masyarakat sekitarnya untuk datang dan berperan aktif dalam pengolahan sampah plastik. Sekaligus menciptakan third place bagi masyarakat sekitarnya.

\section{REFERENSI}

Adharsyah, T. (2019). "Sebegini Parah Ternyata Masalah Sampah Plastik di Indonesia". Retrieved from CNBC Indonesia: https://www.cnbcindonesia.com/lifestyle/20190721140139-33-86420/sebegini-parah-ternyata-masalah-sampah-plastik-di-indonesia, Diakses 2019, August 4

Ariffin, E. (2018). "Indonesia's Plastic Waste Problem". The Asean Post. Retrieved from The Asean Post: https://theaseanpost.com/article/indonesias-plastic-waste-problem-0, Diakses 2019, August 4

Erman, M. (2018). "Opposite Office's Ocean Museum and Recycling Plant Draws Attention to the Plastic Pollution Issue". Retrieved from Designboom: https://www.designboom.com/architecture/opposite-office-ocean-museum-10-29-2018/, Diakses 2019, August 18

Oldenburg, R. (1999). The Great Good Place: Cafes, Coffee Shops, Bookstores, Bars, Hair Salons, and Other Hangouts at the Heart of a Community. New York: Marlowe \& Co.

Peters, A. (2019). "This 'Plasticarium' Shows You What the Plastic-filled Ocean Actually Looks Like". Fast Company. Retrieved from Fast Company: https://www.fastcompany.com/90330680/this-plasticarium-shows-you-what-the-plasticfilled-ocean-actually-looks-like, Diakses 2019, August 18

Jambeck, R. J. (2015). "Plastic Waste Inputs from Land into the Ocean". Science, 347, 768-770. Retrieved from Science Magazine: https://science.sciencemag.org/, Diakses 2019, August 4 Sutanto, A. (2019). Architecture of the Third Place. Universitas Tarumanagara.

Tjahjono, G. (2000). Metode Perancangan Suatu Pengantar Untuk Arsitek dan Perancang. Depok: Universitas Indonesia.

Tuang, Y. F. (1997). Space and Place: The Perspective of Experience. Minnesota: University of Minnesota Press.

Vidler, A. (2015). The Third Typology and Other Essays. Vasel: Actarbirkhauser.

Winata, S. (2019). Open Architecture as the Third Place Architecture. Universitas Tarumanagara.

Winata, S. (2019). The Third Place: All About Human and Their Communitie(s). Universitas Tarumanagara. 